\title{
Trauma of Love and its Betrayal of Mariam as Portrayed in Hosseini's A Thousand Splendid Suns
}

\author{
M. Anu
}

Assistant Profess or of English, K.S.R. college of Arts and Science for Women, Tiruchengodu, Namakkal, Tamil Nadu, India

Email: swanthitha@gmail.com

\begin{abstract}
Khaled Hosseini opened a window to world about the trauma of the Afghans. He knows that English is global language where he can let to the world of their suffering with effective reflection. All most all the characters in the novel A Thousand Splendid suns suffered a lot with their own Karma. Hosseini believes in karma it seems so he mentioned it in all his Novels which includes The Kite Runner and And in Mountain echoed.. Within A Thousand Splendid suns, Khaled Hosseini uses prejudice as a tool to inform this story of betrayal and redemption.
\end{abstract}

Keywords-A Thousand Splendid suns, Trauma, love, Mariam, sufferings, Betrayal, hosseini.

\section{INTRODUCTION}

Love is not just a word. The world is revolving around just because of two things Love and Hard work. Love makes the human kind and hard work makes them to move to future. Without this, the world remains same as in days of Adam and Eve. Love is an ultimate feeling where each creature can feel. It is like a shower to heart and makes the world beautiful all around. Love makes us feel confident and warm even though there is a problem. There is no poet left to praise 'Love'. Love gives meaning for life and makes life even brighter.

But when the person we Love betrays us, it makes a worst pain for ever. The saddest thing in betrayal is that it never comes from enemies. Betrayal is one of the most painful human experiences. Discovering that someone we trusted has deeply hurt us pulls the reality rug from under us.

\section{Trauma of Love}

In A Thousand Splendid Suns, Love may not conquer all, but it is a stronger tie than many other social bonds, from social class to ethnic status. Love makes the novel's characters act in sometimes irrational ways, and their erratic behaviour can often be explained by the strong loyalty that stems from Love. Mariam, Harami--an illegitimate child. This word has a lasting impact on
Mariam, defining her status in Afghanistan and establishing a life-long struggle with self-worth. Raised by a sacrificing but bitter mother and neglecting father, Mariam is taught from a young age that she "would never have a legitimate claim to the things other people had, things such as Love, family, home, acceptance" (4).Nana her Mother made Mariam understand that, she was illegitimate person who would never have legitimate claim.

Mariam got betrayed by her father Jalil. It was Mariam's fifteenth birthday, she asked her father to take her to see the cinema, the carton and the puppet boy along with all her brothers and sisters. However, Jalil doesn't agree and explains to Mariam the impossibility of the idea by giving various excuses. Mariam believed that "other than Jalil, she thought there was no one in the world who understands her better" (17). Jalil a prosperous business owner is shamed by the birth of Mariam, his illegitimate child with his housekeeper. Instead of facing the consequences, he succumbs to the wishes of his wives and distances himself from Mariam as a guilty secret. Visiting once a week with gifts and affection, he assuages his guilt and wins the heart of his young daughter. As she grows older, Mariam continues to note the difference between how Jalil treats her and how he treats her legitimate half-siblings.

Mariam is betrayed by her father, who marries her off to a much older man Rasheed, in order to conceal his own shame. The ultimate betrayal of Jalil comes when he marries her off to a middle-aged man without her consent, leading her to declare: "Don't come. I don't want to hear from you. Ever" (50). And Mariam last word to Jalil is "I used to worship you... on Thursday, I sat for hours waiting for you... I thought about you all the time.. I didn't know you were ashamed of me" (54). True to her word, Mariam never sees himagain. Just as she eventually forgives her mother, she also reconciles herself to her father's actions. Meanwhile, Jalil suffers as he finally realizes the consequences of his actions. He longs for the daughter he never acknowledged and realizes that he has sacrificed his 
happiness for "fear of losing face" and "staining my socalled name".(405)

Rasheed who used to treat Mariam like Fairy Tale's as expecting for boy baby. Meanwhile a change had come over Rasheed ever since the day of abortion. "In the four years since the day at the bathhouse, there had been six more cycles of hopes raised then dashed, each lose, each collapse, each trip to the doctor more crushing for Mariam than the last".(98)

He terrorizes her, beating her at the smallest perceived offense and making her feel like "the goat, released in the tiger's cage, when the tiger first looks up from his paws, begins to growl" (240). Once she loses her baby, Rasheed forces her to eat pebbles, a form of stoning. With each miscarriage, Rasheed's behaviour becomes more brutal, inhuman, and distant.

When Rasheed tries to marry Lalila for a boy bay, Mariam never offered the love to Laila. But Later when Laila gave a birth to Aziza, day by day Mariam started loving the companionship of Lalia and Aziza. Mariam soon becomes a second mother to Aziza.When Mariam carries Aziza for the time she felt that "Love had never been declared to her so guilelessly so unreservedly". And after all these years of rattling loose "She had found in this little creature the first true connection in her life of false, failed connection".(246)

The poignant scene at the end of the novel when Laila receives a letter from Jalil meant for Mariam makes clear that his Love for her was never entirely stamped out . The Letter says about the Jalil's Love for Mariam. And it goes:

I have dreams for you too Mariam jo. I miss the sounds of your voice, your laughter. I miss reading to you, and all those times we fished together. Do you remember all those times we fished together?? You were a good daughter, Mariam jo, and i cannot even think of you without felling shame and regret.(393)

He says regret for Mariam comes like a ocean. All the words in the letter seem a true feeling of a guilty father.

This is just a punishment or those who have been heartless, to understanding only when nothing can be undone. Now all i can do is say that you were a good daughter, Mariam jo, and that i never deserved you. Now all i can do is ask for your forgiveness. So forgive me, Mariam jo. Forgive me. Forgive me. (394)
Jalil hoped that Mariam will forgive him once and believes that Mariam will knock on his door one more time and give him the chance to open it this time, to welcome her, to take her in his arms, his daughter, as he should have all those years ago.

\section{CONCLUSION}

The author concludes this novel by saying that Mariam, "She was leaving the world as a women who had Loved and been Loved back. She was leaving it as a friend, a companion, a guardian, a mother. A pers on of consequences at last"(370).

\section{REFERENCES}

[1] Hosseini, Khaled. A Thousand Splendid Suns. Great Britain: Blooms bury Publication, 2008.Print.

[2] Hosseini, Khaled. "About." The Khaled Hosseini Foundation. UNHCR, Sept. 2009. Web. 10 May 2010. http://www.khaledhos seinifoundation.org/. 